\title{
Pawet Gacek
}

Komenda Główna Policji

p.gacek@wp.pl

ORCID: https://orcid.org/0000-0001-6365-3146

\section{Zawieszenie oraz potrącenie policjantowi uposażenia na podstawie art. 126 ustawy z dnia 6 kwietnia 1990 r. o Policji}

http://dx.doi.org/10.12775/SIT.2020.020

\section{Wprowadzenie. Szczególny charakter służby}

Policja jest organizacją zobligowaną do zapewnienia bezpieczeństwa i porządku publicznego ${ }^{1}$. Jest to jej nadrzędne zadanie $^{2}$, ponieważ jest podstawową formacją, której je przydzielono ${ }^{3}$. Treść art. 1 ust. 1 ustawy z dnia 6 kwietnia 1990 r. o Policji ${ }^{4}$ określa cele i zadania

${ }^{1}$ W. Maciejko, Osobowe prawo administracyjne, Warszawa 2008, s. 149; W. Maciejko, M. Rojewski, A. Suławko-Karetko, Postępowanie administracyjne. Zarys wykładu części szczególnej, Warszawa 2011, s. 133.

${ }^{2}$ B. Opaliński, P. Szustakiewicz, Policja. Studium administracyjnoprawne, Warszawa 2013, s. 91.

${ }^{3}$ E. Olejniczak-Szałowska, w: Prawo administracyjne materialne. Pojęcia, instytucje, zasady, red. Z. Duniewska, B. Jaworska-Dębska, M. Stahl, Warszawa 2014, s. 662.

4 Tekst jednolity: Dz.U. z 2020 r. poz. 360 ze zm. 
Policji. Ich przykładowa egzemplifikacja została natomiast zamieszczona w art. 1 ust. 2 ustawy o Policji. Nie jest to wyczerpujący katalog (numerus clausus), ale jedynie pewien zbiór najważniejszych zadań, jakie zostały przydzielone tej formacji. Ich realizacja wymaga jednak zapewnienia rzeczywistych wykonawców, którymi są funkcjonariusze tworzący szeregi tej organizacji. Sama bowiem formacja nie jest zdolna do wypełnienia swojej misji bez członków, tj. funkcjonariuszy. Czynności służbowe podejmowane przez policjanta na zajmowanym przez niego stanowisku służbowym stanowią o cząstkowej realizacji zadań nałożonych na określoną komórkę organizacyjną jednostki Policji. Z kolei suma zadań wykonanych przez funkcjonariuszy wszystkich jednostek Policji jest świadectwem realizacji ustawowych zadań Policji.

Stąd też konieczne stało się ustanowienie w tej organizacji mechanizmów będących instrumentami prawnymi mającymi stworzyć warunki do osiągnięcia celu, dla którego formacja ta została powołana do życia. Przyjęto w niej właściwą służbom mającym charakter zmilitaryzowany strukturę organizacyjną opartą na hierarchiczności i podporządkowaniu podwładnych wobec przełożonych $^{5}$. Jak słusznie zaznacza Jan Paweł Tarno, hierarchiczny model tej zmilitaryzowanej (paramilitarnej) organizacji, tj. umundurowanej i uzbrojonej, wynika wprost $z$ charakteru jej zadań ${ }^{6}$. Nadrzędnym i najbardziej istotnym $z$ nich jest zapewnienie bezpieczeństwa i porządku publicznego.

Kształt struktury organizacyjnej nie jest jednak jedynym instrumentem, który stwarzać ma optymalne warunki do realizacji ustawowych zadań Policji. Innym jest przyjęty w tej organizacji szczególny rodzaj więzi prawnej, jaka zostaje zainicjowana pomiędzy osobą fizyczną (policjantem) a podmiotem zatrudniającym (przełożonym właściwym w sprawach osobowych). Jest nią stosunek służbowy. Ma

${ }_{5}$ Zob. zarządzenie nr 30 Komendanta Głównego Policji z dnia 16 grudnia 2013 r. w sprawie funkcjonowania organizacji hierarchicznej w Policji (Dz.Urz. KGP z 2013 r. poz. 99 ze zm.).

${ }^{6}$ J.P. Tarno, Policja jako organ administracji o kompetencjach szczególnych, w: Policja w strukturach administracji publicznej, red. A. Babiński, P. Bogdalski, Szczytno 2005, s. 9. 
on charakter stricte administracyjnoprawny ${ }^{7}$. Jego charakterystycznymi cechami są zwiększona dyspozycyjność i podporządkowanie policjanta w służbie ${ }^{8}$. Zastrzec bowiem należy, że służba w Policji nie jest zwykłą pracą najemną ${ }^{9}$. Policjant nie jest pracownikiem w rozumieniu art. 2 k.p., a przełożony właściwy w sprawach osobowych nie jest pracodawcą w rozumieniu art. 3 k.p. Funkcjonariusz nie wykonuje pracy, ale pełni służbę, za którą nie otrzymuje

7 Szerzej na temat stosunku służbowego zob. T. Kuczyński, E. Mazurczak-Jasińska, J. Stelina, Stosunek służbowy, w: System prawa administracyjnego. Tom 11, red. R. Hauser, Z. Niewiadomski, A. Wróbel, Warszawa 2011 ; P. Szustakiewicz, Stosunki służbowe funkcjonariuszy służb mundurowych i żołnierzy zawodowych jako sprawa administracyjna, Warszawa 2012; M. Wieczorek, Charakter prawny stosunków służbowych funkcjonariuszy służb mundurowych, Toruń 2017; P. Gacek, Nawiązanie stosunku służbowego z funkcjonariuszem Policji, „Administracja. Teoria - Dydaktyka - Praktyka” 2011, nr 2(23), s. 76 i n.

${ }^{8}$ Ma to bezpośrednie odzwierciedlenie w przyjętej konstrukcji czasu służby. Już sama nazwa wskazuje, że nie jest on czasem pracy w rozumieniu art. $128 \S 1$ Ustawy z dnia 26 czerwca 1974 r. Kodeks pracy - tekst jednolity: Dz.U. z 2020 r. poz. 1320 ze zm. (Szerzej na ten temat zob. P. Gacek, Czas służby a czas pracy - wybrane aspekty. Przyczynek do dyskusji, „Policja. Kwartalnik kadry kierowniczej Policji” 2014, nr 2, s. 41 i n.; idem, Służba pełniona przez policjanta $w$ ramach dyżuru domowego, „Policja. Kwartalnik kadry kierowniczej Policji” 2017, nr 2, s. 27 i n.). Zgodnie z art. 33 ust. 1 ustawy o Policji czas pełnienia służby policjanta jest określony wymiarem jego obowiązków. Obowiązki policjanta, a tym samym przydzielone mu zadania (czynności służbowe), są punktem centralnym, wokół którego kształtują się ramy jego czasu służby. Jak słusznie podkreśla się w doktrynie, „Niedopuszczalna jest więc sytuacja, gdy policjant nie wykonuje zadania lub nie chce podjąć czynności służbowej, uznając, że skończył mu się 8-godzinny dzień pracy lub odmawia wykonywania zadań w niedzielę lub święta. [...] Charakter zadań nałożonych na Policję powoduje, że funkcjonariusze mają obowiązek wykonywać zadania również wtedy, gdy inne grupy zawodowe mają dni wolne od pracy. Oczywistym jest bowiem, że bezpieczeństwo wewnętrzne jest zjawiskiem o charakterze dynamicznym, które cały czas powinno być chronione” (B. Opaliński, M. Rogalski, P. Szustakiewicz, Uwagi do art. 33, w: Ustawa o Policji. Komentarz, Warszawa 2020, Legalis). Czas służby nie jest zatem wyznaczany jako zwykłe godziny pracy, ale musi być dostosowany do realnych potrzeb służby (,funkcjonariusz jest zobowiązany do wykonywania obowiązków służbowych przez cały czas konieczny do realizacji powierzonych mu zadań" - wyrok NSA z dnia 6 lutego 2018 r., I OSK 721/18, Legalis nr 1740519).

${ }^{9}$ W. Kotowski, Ustawa o Policji. Komentarz, Warszawa 2008, s. 380. 
wynagrodzenia, a uposażenie ${ }^{10}$. Jest on bowiem zobowiązany do jej pełnienia, nawet $z$ narażeniem własnego życia, zgodnie $z$ rotą złożonego ślubowania (art. 27 ustawy o Policji) ${ }^{11}$. Służba publiczna, bo w takich kategoriach należy rozpatrywać służbę w Policji, nacechowana jest $z$ jednej strony istnieniem szczególnych uprawnień, ale $z$ drugiej obowiązków i ograniczeń nieznanych innym grupom zawodowym, których podstawą zatrudnienia jest stosunek pracy. Ten wyższy stopień dyspozycyjności zdeterminował ustawodawcę do szczególnego potraktowania stosunku służbowego i wyodrębnienia go spośród innych stosunków prawnych ${ }^{12}$. Jak słusznie zauważa Tadeusz Zieliński, kryterium odgraniczającym stosunek służbowy od stosunku pracy jest tzw. pełna dyspozycyjność. Nasilenie w nim pierwiastków władczych jest tak duże, że reżim prawa pracy musi ustąpić przepisom prawa administracyjnego ${ }^{13}$. Przepisy prawa pracy byłyby tu mało przydatne ${ }^{14}$, a tym samym nieefektywne.

Z kolei uposażenie jest pewnym ekwiwalentem za czas poświęcony służbie oraz rekompensatą za zwiększoną, bo „pełną”, dyspozycyjność i gotowość podjęcia działań nawet $\mathrm{z}$ narażeniem własnego życia i zdrowia. Istnieją jednak przypadki, które pozwalają na zawieszenie uposażenia, a także jego potrącenie. Służy temu konstrukcja prawna zamieszczona w art. 126 ustawy o Policji. Nie tylko jest to instrument o charakterze prewencyjnym, ale może też być

10 „Uposażenie nie może być utożsamiane ze znanym Kodeksowi pracy wynagrodzeniem” (B. Opaliński, M. Rogalski, P. Szustakiewicz, Uwagi do art. 99, w: Ustawa).

11 Wyrok NSA z dnia 27 sierpnia 2013 r., I OSK 1902/12, Legalis nr 1924883; wyrok NSA z dnia 10 lutego 2012 r., I OSK 1056/11, Legalis nr 448397; wyrok NSA z dnia 24 stycznia 2007 r., I OSK 664/06, Legalis nr 657705.

12 „Bezspornym jest, że stosunki służbowe funkcjonariuszy wymienionych służb [w tym Policji - P. G.] mają charakter administracyjnoprawny, mieszczą się bowiem w określonej grupie stosunków prawnych specyficznie regulowanych" (uchwała TK $z$ dnia 25 stycznia 1995 r., W 14/94, Legalis nr 10240). Nie są zatem stosunkami pracy (T. Szankin, Stużba w Policji, w: Prawo policyjne, red. M. Czuryk, M. Karpiuk, J. Kostrubiec, K. Orzeszyna, Warszawa 2014, s. 200).

${ }^{13}$ T. Zieliński, Stosunek prawa pracy do prawa administracyjnego, Warszawa 1977, s. 181.

${ }^{14}$ Uchwała SN - Izba Administracyjna, Pracy i Ubezpieczeń Społecznych z dnia 5 grudnia 1991 r., I PZP 60/91, Legalis nr 27539. 
instrumentem represyjnym - dyscyplinującym policjantów, którzy z nieuzasadnionych przyczyn nie pełnili służby i nie wykonywali obowiązków służbowych, a tym samym, którzy mogli zaburzyć prawidłowy proces realizacji zadań nałożonych na tę organizację. Jeśli bowiem policjant nie wykonuje swoich obowiązków, naturalne jest, że przydzielone mu zadania muszą wykonać inni funkcjonariusze, którym zwiększa się automatycznie zakres własnych obowiązków do wykonania. To może skutkować spadkiem efektywności w obszarze prawidłowości i rzetelności ich realizacji. Mechanizm, o którym mowa, pozwala na czasowe zawieszenie uposażenia lub jego potrącenie. Zagadnienie to, jak się wydaje, ma istotne znacznie dla przełożonych zobligowanych do nadzoru nad realizacją nałożonych na jednostki i komórki organizacyjne jednostek Policji zadań oraz nad podległymi im funkcjonariuszami. Temat ten nie był dotychczas przedmiotem szerszych rozważań zarówno w doktrynie, jak i judykaturze. Stanowi to zatem przyczynek do zaprezentowania głębszej refleksji nad tą sprawą. Ponieważ jednak zagadnienie to immanentnie związane jest $z$ uposażeniem, rozważania objęte niniejszym opracowaniem należy poprzedzić omówieniem kwestii związanych $z$ istotą uposażenia.

\section{Uposażenie policjanta}

Uposażenie $^{15}$ jest świadczeniem publicznoprawnym, które służy zrekompensowaniu ograniczeń i innych obowiązków, jakie immanentnie związane są ze służbą ${ }^{16}$. Ma ono, tak samo jak stosunek służbowy, charakter administracyjnoprawny ${ }^{17}$. Wobec tego rozstrzygnięcie w kwestii uposażenia również następuje w drodze kwalifi-

15 Stownik wiedzy o Policji, red. P. Bogdalski, M. Świderski, K.A. Wojtaszczyk, Warszawa 2015, s. 273 - definiuje uposażenie jako obowiązkowe, okresowe, majątkowe świadczenie otrzymywane przez policjanta za pełnioną służbę.

${ }^{16}$ B. Opaliński, M. Rogalski, P. Szustakiewicz, Uwagi do art. 99, w: Ustawa; B. Opaliński, P. Szustakiewicz, Policja, s. 144; W. Maciejko, A. Korcz-Maciejko, Postępowanie $w$ sprawach osobowych $w$ Policji, Wrocław 2010, s. 111 i n.

17 P. Szustakiewicz, Stosunki, s. 188. 
kowanego aktu administracyjnego, czyli decyzji administracyjnej ${ }^{18}$. Sama natomiast wypłata uposażenia jest czynnością materialno-techniczną ${ }^{19}$, która nie wymaga wydania decyzji w tym zakresie.

$Z$ kolei z treści art. 99 ust. 1 ustawy o Policji wynika, że prawo do uposażenia powstaje $z$ dniem mianowania policjanta na stanowisko służbowe. Nie oznacza to jednak, że prawo to materializuje się i automatycznie podlega wypłacie ipso iure w chwili mianowania policjanta na konkretne stanowisko służbowe, gdyż treść tego przepisu nie może być odczytywana w oderwaniu od art. 42 ust. 4 ustawy o Policji, zgodnie $z$ którym prawo do uposażenia powstaje $z$ dniem podjęcia służby, chyba że po zgłoszeniu do służby zaistniały okoliczności usprawiedliwiające niepodjęcie tej służby. Uposażenie jest bowiem świadczeniem pieniężnym przysługującym i wypłacanym $z$ tytułu pełnionej przez funkcjonariusza służby ${ }^{20}$. W judykaturze został ugruntowany pogląd, zgodnie $z$ którym istnieje związek między prawem do otrzymywania uposażenia a wykonywaniem obowiązków służbowych ${ }^{21}$. Jeśli zatem czynny funkcjonariusz nie podejmuje

${ }^{18}$ Wyrok NSA z dnia 17 maja 2017 r., I OSK 2219/15, Legalis nr 1652048, a także uchwała Składu Siedmiu Sędziów NSA z dnia 10 kwietnia 2006 r., I OPS 3/06, Legalis nr 75152 (dotyczy żołnierzy zawodowych) oraz wyrok SN - Izba Administracyjna, Pracy i Ubezpieczeń Społecznych z dnia 5 września 1991 r., I PRN 39/91, Legalis nr 36948, uchwała SN - Izba Administracyjna, Pracy i Ubezpieczeń Społecznych z dnia 5 grudnia 1991 r., I PZP 60/91.

19 Wyrok WSA w Poznaniu z dnia 18 kwietnia 2019 r., IV SA/Po 1140/18, Legalis $\mathrm{nr} 1922036$.

${ }^{20}$ P. Zając, Uwagi do art. 99, w: Ustawa o Policji. Komentarz, red. K. Chałubińska-Jentkiewicz, J. Kurek, Warszawa 2020, Legalis; M. Lew, Policja, w: Stosunek służbowy $w$ formacjach mundurowych, red. W. Maciejko, P. Szustakiewicz, 2016, Legalis; M. Liwo, Status służb mundurowych i funkcjonariuszy $w$ nich zatrudnionych, Warszawa 2013, s. 325, W. Maciejko, A. Korcz-Maciejko, Postępowanie, s. 111 . Por. również M. Zorska, Komentarze do ustaw z 31 stycznia 1950 r. o stosunku służbowym funkcjonariuszów Milicji Obywatelskiej i z 31 stycznia 1959 r. o zaopatrzeniu emerytalnym funkcjonariuszów Milicji Obywatelskiej i ich rodzin, Warszawa 1960, s. 25 - autorka stwierdza, że jest to podstawowe uprawnienie wynikające ze służby.

${ }^{21}$ Wyrok WSA w Warszawie z dnia 28 lipca 2016 r., II SA/Wa 389/16, Legalis nr 1514245. Por. także wyroki: WSA w Warszawie $z$ dnia 21 stycznia 2019 r., II SA/Wa 671/18, Legalis nr 1917172; WSA w Bydgoszczy z dnia 5 czerwca 2018 r., II SA/Bd 1271/17, Legalis nr 1836776; WSA w Warszawie 
służby, to - co do zasady - nie ma uprawnienia do otrzymywania uposażenia $^{22}$. Niewykonywanie przez funkcjonariusza służby, poza ściśle wskazanymi w przepisach pragmatyki służbowej wypadkami, kiedy zachowuje on prawo do uposażenia (np. urlop wypoczynkowy, choroba), pozbawia go prawa do niego ${ }^{23}$. Tym samym pozostawanie funkcjonariusza w stosunku służbowym jest warunkiem koniecznym, lecz niewystarczającym do tego, by przysługiwało mu uposażenie ${ }^{24}$. Musi on również pełnić (rzeczywiście świadczyć) tę służbę.

Policjant jest uprawniony do otrzymania jednego uposażenia z tytułu pełnionej służby (art. 99 ust. 2 ustawy o Policji). Składa się ono $\mathrm{z}$ uposażenia zasadniczego i $\mathrm{z}$ dodatków do uposażenia (art. 100 ustawy o Policji) ${ }^{25}$.

Warto zauważyć, że uposażenie wraz $\mathrm{z}$ dodatkami o charakterze stałym płatne jest bezpośrednio do rąk policjanta (art. 105 ust. 1 ustawy o Policji), chyba że wypłata taka następuje w formie bezgotówkowej. Wówczas pisemne porozumienie pomiędzy płatnikiem a policjantem określa warunki, na jakich to następuje (art. 105 ust. 5 ustawy o Policji). Uposażenie zasadnicze i dodatki do uposażenia o charakterze stałym są płatne miesięcznie $z$ góry w pierwszym dniu roboczym każdego miesiąca, ale minister właściwy do spraw wewnętrznych może określić w drodze rozporządzenia inne terminy płatności dodatków do uposażenia o charakterze stałym, uwzględniając, które $z$ nich są płatne miesięcznie $z$ dołu (art. 105

z dnia 25 czerwca 2015 r., II SA/Wa 1851/14, Legalis nr 1335812; WSA w Warszawie $z$ dnia 20 czerwca 2013 r., II SA/Wa 70/13, Legalis nr 1925397; WSA w Szczecinie z dnia 25 kwietnia 2012 r., II SA/Sz 150/12, Legalis nr 557308; WSA w Warszawie $z$ dnia 26 października 2011 r., VIII SA/Wa 671/11, Legalis nr 392912 (dotyczy funkcjonariusza ABW); WSA w Kielcach z dnia 7 lipca 2011 r., II SA/Ke 370/11, Legalis nr 377239 - i tam powołane orzecznictwo.

${ }^{22}$ M. Grześków, Ogólna charakterystyka, rozwój regulacji i źródła prawa stosunków zatrudnienia w służbach zmilitaryzowanych, w: Nawiązywanie stosunków zatrudnienia $w$ służbach zmilitaryzowanych, Warszawa 2020, Legalis - i tam powołane orzecznictwo, a także P. Szustakiewicz, Stosunki, s. 196.

${ }^{23}$ Wyrok NSA z dnia 24 kwietnia 2012 r., I OSK 1725/11, Legalis nr 777260.

${ }^{24}$ Wyrok NSA z dnia 7 lipca 2010 r., I OSK 158/10, Legalis nr 305226.

${ }^{25}$ Omówienie tych zagadnień przekracza jednak ramy niniejszego opracowania. Szerzej na ten temat zob. W. Maciejko, A. Korcz-Maciejko, Postępowanie, s. 109 i n.; P. Szustakiewicz, Stosunki, s. 188 i n. 
ust. 3 ustawy o Policji) ${ }^{26}$. Jeśli natomiast wypłata uposażenia następuje w formie bezgotówkowej, to nie może ona nastąpić wcześniej niż $\mathrm{w}$ terminach określonych $\mathrm{w}$ art. 105 ust. 2-4 ustawy o Policji.

Wynika $z$ tego, że pragmatyka służbowa statuuje zasadę, zgodnie z którą uposażenie płatne jest policjantowi z góry. Przewidziano także możliwość określenia innych terminów płatności w odniesieniu do dodatków o charakterze stałym, o których mowa w art. 105 ust. 3 ustawy o Policji ${ }^{27}$. Z kolei terminy wypłaty dodatków do uposażenia niemających charakteru stałego wynikają $z$ przepisów szczególnych, regulujących warunki ich otrzymywania. Inne terminy wypłaty uposażenia mogą wynikać z zawartego porozumienia, o którym mowa w art. 105 ust. 5 ustawy o Policji, jeśli wypłata dokonywana jest $w$ formie bezgotówkowej, $z$ tym jednak zastrzeżeniem, że terminy te nie mogą być ustalone wcześniej od tych, które określają przepisy art. 105 ust. 2-4 ustawy o Policji.

Regułą jest więc (i potwierdza to również praktyka), że uposażenie płatne jest za służbę, która dopiero będzie pełniona przez policjanta. Istotą uposażenia jest natomiast to, że przysługuje ono za pełnioną służbę. Przyznanie i wypłata uposażenia za służbę, która dopiero ma być świadczona, wymaga zatem następczego zweryfikowania, czy $\mathrm{w}$ istocie policjant ją pełnił, a tym samym, czy uposażenie zostało mu przyznane i wypłacone zasadnie.

\section{Istota zawieszenia i potrącenia uposażenia}

Zgodnie art. 126 ust. 1 ustawy o Policji policjantowi, który samowolnie opuścił miejsce pełnienia służby albo pozostaje poza nim lub nie podejmuje służby, zawiesza się uposażenie od najbliższego terminu

${ }^{26}$ Terminy wypłaty innych świadczeń i należności pieniężnych oraz dodatków do uposażenia, niewymienionych w art. 105 ust. 2 ustawy o Policji, określają przepisy w sprawie warunków ich otrzymywania (art. 105 ust. 4 ustawy o Policji).

27 Minister właściwy do spraw wewnętrznych nie skorzystał jak dotąd $z$ tego uprawnienia (P. Zając, Uwagi do art. 99, w: Ustawa). 
płatności. Jeżeli policjant pobrał już za czas nieusprawiedliwionej nieobecności uposażenie, potrąca mu się odpowiednią część uposażenia przy najbliższej wypłacie. Natomiast w razie uznania nieobecności za usprawiedliwioną, wypłaca się policjantowi zawieszone uposażenie. $Z$ kolei w przypadku nieobecności nieusprawiedliwionej policjant traci za każdy dzień nieobecności 1/30 część uposażenia miesięcznego (w myśl art. 126 ust. 2 ustawy o Policji). Stosownie do art. 126 ust. 3 ustawy o Policji przepisy art. 126 ust. 1 i 2 tej ustawy stosuje się odpowiednio w razie zawinionej niemożności pełnienia przez policjanta obowiązków służbowych.

Analizując treść przepisu art. 126 ust. 1 ustawy o Policji, można w sposób niebudzący wątpliwości stwierdzić, że ustawodawca przewidział w nim dwie odrębne, niezależne i niekonkurencyjne wobec siebie instytucje. Ich zastosowanie wymaga bowiem zmaterializowania się odrębnych przesłanek. Inne są także cele, które mają osiągnąć te konstrukcje. Zawieszenie uposażania zmierza do czasowego wstrzymania wypłaty uposażenia policjantowi w sytuacji, gdy istnieje uzasadnione przypuszczenie, że może być ono nienależne, po to, by nie była konieczna jego następcza egzekucja. $Z$ kolei potrącenie dokonywane jest wówczas, gdy ustalono, że wypłacone policjantowi z góry uposażenie nie było należne. Potrącenie trwale pozbawia policjanta takiego uposażenia. Obie zatem konstrukcje prawne pełnią funkcję ochronną wobec interesu Skarbu Państwa, a tym samym interesu społecznego, który w tym przypadku zbieżny jest $\mathrm{z}$ interesem służby (dobrem służby). W interesie tym leży, aby policjanci faktycznie realizowali powierzone im zadania (czynności), za wykonywanie których otrzymywaliby uposażenie. Co także istotne, instytucja zawarta w art. 126 ust. 1 ustawy o Policji jest odrębną od tej, która uregulowana została w art. 127 ustawy o Policji, a która także umożliwia potrącenie funkcjonariuszowi uposażenia. Wspólną cechą instytucji zawieszenia i potrącenia uposażenia jest to, że obie obligują do podjęcia określonego działania, tj. zawieszenia bądź potrącenia uposażenia, jeśli zaistnieją ku temu przesłanki ${ }^{28}$. Swiadczy o tym ta część przepisu art. 126

${ }^{28}$ Wyrok NSA z dnia 17 maja 2017 r., I OSK 2575/15, Legalis nr 1652049. 
ust. 1 ustawy o Policji, która stanowi, że „zawiesza się uposażenie” oraz „potrąca się odpowiednią część uposażenia”, a nie, że „może” ono być zawieszone lub potrącone. Pomimo jednak różnic, jakie zachodzą pomiędzy obiema instytucjami, mogą być one ze sobą funkcjonalnie sprzężone. Zawieszenie uposażenia może w konsekwencji doprowadzić do jego utraty. Wspólne dla obu konstrukcji jest też to, że następują one w drodze decyzji administracyjnej ${ }^{29}$. Ich weryfikacja odbywa się w administracyjnym toku instancji, a po jego wyczerpaniu na drodze sądowoadministracyjnej. Organem właściwym rzeczowo do wydania obu decyzji jest przełożony właściwy w sprawach osobowych, o którym mowa w art. 32 ust. 1 ustawy o Policji. Od wydanych przez niego decyzji przysługuje odwołanie do wyższego przełożonego (art. 32 ust. 2 ustawy o Policji), chyba że organem I instancji był Komendant Główny Policji. Wówczas nie przysługuje od niego odwołanie, ale można złożyć wniosek o ponowne rozpatrzenie sprawy ${ }^{30} . Z$ kolei po wyczerpaniu środków zaskarżenia przysługuje uprawnienie do złożenia skargi do sądu administracyjnego, zgodnie $z$ art. 52 § 1 ustawy $z$ dnia 30 sierpnia 2002 r. - Prawo o postępowaniu przed sądami administracyjnymi ${ }^{31}$ (oczywiście $z$ uwzględnieniem art. $52 \S 2$ i 3 tej ustawy).

${ }^{29}$ Wyrok NSA z dnia 17 maja 2017 r., I OSK 2219/15; wyrok NSA z dnia 17 maja 2017 r., I OSK 2575/15; wyrok WSA w Szczecinie z dnia 31 sierpnia 2016 r., II SA/Sz 452/16, Legalis nr 1547851; wyrok WSA w Warszawie $z$ dnia 27 października 2015 r., II SA/Wa 471/15, Legalis nr 1383754; wyrok WSA w Warszawie $z$ dnia 9 kwietnia 2015 r., II SA/Wa 1805/14, Legalis nr 1245241; wyrok WSA w Warszawie $z$ dnia 9 kwietnia 2015 r., II SA/Wa 1710/14, Legalis nr 1244683; postanowienie WSA w Gdańsku z dnia 12 lutego 2015 r., III SA/ /Gd 1/15, Legalis nr 1278220.

${ }^{30}$ Zgodnie bowiem $z$ treścią art. 32 ust. 3 ustawy o Policji od decyzji wydanej przez Komendanta Głównego Policji przysługuje odwołanie do ministra właściwego do spraw wewnętrznych, ale wyłącznie w sprawach wynikających z art. 32 ust. 1 ustawy o Policji. W pozostałych przypadkach stosuje się przepisy k.p.a. Zgodnie $z$ art. $127 \S 3$ k.p.a. od decyzji wydanej w I instancji przez ministra, w rozumieniu art. $5 \S 2$ pkt 4 k.p.a., odwołanie nie przysługuje, ale można złożyć wniosek o ponowne rozpatrzenie sprawy. Komendant Główny Policji jest natomiast centralnym organem administracji rządowej (art. 5 ust. 1 ustawy o Policji), wobec czego spełnia wymogi określone w art. $5 \S 2$ pkt 4 k.p.a.

31 Tekst jednolity: Dz.U. z 2019 r. poz. 2325 ze zm. 
Instytucja potrącenia, jak zostało to wspomniane, dotyczy takich sytuacji, w których policjant pobrał już uposażenie za określony okres, tj. miesiąc, w którym zobowiązany był do pełnienia służby. Regułą jest bowiem, że prawo do uposażenia materializuje się z początkiem miesiąca, w którym policjant miał realizować swój obowiązek pełnienia służby (art. 105 ust. 2 ustawy o Policji). Obliguje to do następczej weryfikacji, czy w okresie miesiąca, za który dokonano wypłaty uposażenia, nie wystąpiły okoliczności mogące mieć wpływ na wysokość pobranego przez policjanta uposażenia. Potrącenie może jednak nastąpić, jeśli zmaterializuje się przesłanka warunkująca zastosowanie tej instytucji. Jest nią ustalenie nieusprawiedliwionej nieobecności policjanta w służbie. O tym, w jaki sposób policjant zobowiązany jest do usprawiedliwienia swojej nieobecności w służbie, a także jakie sytuacje przesądzają o tym, że określona absencja jest usprawiedliwiona, stanowi zawsze przepis szczególny zawarty w pragmatyce służbowej ${ }^{32}$. Konieczne jest ponadto wskazanie na rozkaz i polecenie służbowe jako podstawy stanowiącej usprawiedliwienie nieobecności funkcjonariusza w służbie. Funkcjonariusz jako członek organizacji mającej strukturę zhierarchizowaną i zmilitaryzowaną zobligowany jest do wykonywania rozkazów i poleceń wydanych mu przez uprawnione podmioty ${ }^{33}$. Ich niewykonanie lub nienależyte wykonanie sankcjonowane jest odpowiedzialnością dyscyplinarną ${ }^{34}$. Wyjątek stanowi

${ }^{32}$ Są nimi m.in. art. $121 \mathrm{c}$ w zw. z art. $121 \mathrm{~b}$ ust. 2 ustawy o Policji, przepisy rozporządzenia Ministra Spraw Wewnętrznych z dnia 14 maja 2013 r. w sprawie szczegółowych praw i obowiązków oraz przebiegu służby policjantów (Dz.U. z 2020 r. poz. 1113 ze zm.), np. § 9, § 10, § 24, a także przepisy rozporządzenia Ministra Spraw Wewnętrznych z dnia 19 września 2014 r. w sprawie urlopów policjantów (Dz.U. z 2014 r. poz. 1282 ze zm.), np. § 26.

${ }^{33} \mathrm{Tj}$. przez przełożonego (§ 15 pkt 1 zarządzenia nr 30 Komendanta Głównego Policji $z$ dnia $z$ dnia 16 grudnia 2013 r. w sprawie funkcjonowania organizacji hierarchicznej w Policji) albo policjanta starszego stopniem, w przypadkach wskazanych w przepisie szczególnym (§ 21 tego zarządzenia).

${ }^{34}$ Stanowi przypadek naruszenia dyscypliny służbowej - art. 132 ust. 3 pkt 2 ustawy o Policji. Por. wyrok NSA z dnia 4 maja 2016 r., I OSK 3211/14, Legalis $\mathrm{nr} 1511101$. 
art. 58 ust. 2 ustawy o Policji ${ }^{35}$, ale odmowa musi być uzasadniona popełnieniem przestępstwa ${ }^{36}$, które nastąpiłoby wskutek wykonania rozkazu lub polecenia. Ciężar dowodu w tym zakresie obciąża jednak samego policjanta, który odmawia wykonania rozkazu lub polecenia $^{37}$. Jest to o tyle istotne, że w innych sytuacjach policjant nie jest uprawniony do kwestionowania wydanego mu rozkazu lub polecenia, nawet w sytuacji, gdyby nie miał on oparcia w przepisach prawa. Zasada, o której mowa, jest wyrazem silnej podległości służbowej, panującej w formacjach zorganizowanych na zasadach hierarchiczności. Możliwość swobodnego kwestionowania rozkazów lub poleceń przez podwładnego podważałaby reguły będące podstawą funkcjonowania tej organizacji. Mogłoby to w konsekwencji doprowadzić do jej paraliżu ${ }^{38}$. Jeśli zatem na gruncie ustawy o Policji obowiązuje zasada podległości służbowej policjantów, to wszelkie wyjątki od niej powinny być wykładane możliwie wąsko, a wątpliwości przesądzane na rzecz obowiązku wykonania rozkazu lub polecenia przez policjanta ${ }^{39}$. Funkcjonariusz jest zobligowany wypełnić ten obowiązek niezależnie od swoich subiektywnych odczuć, niezależnie do tego, czy akceptuje stanowisko przełożonego, jak również wtedy, gdy uważa, że jest ono przejawem niesprawiedliwego potraktowania jego osoby ${ }^{40}$, a także gdy jego wykonanie

${ }^{35}$ Gdy wykonanie rozkazu lub polecenia łączy się z popełnieniem przestępstwa. W takich sytuacjach policjant powinien o tym zameldować Komendantowi Głównemu Policji z pominięciem drogi służbowej (art. 58 ust. 3 ustawy o Policji).

36 Przy czym pojęcie przestępstwa musi być odczytywane jako czyn lub okoliczność dająca się tak kwalifikować w znaczeniu niewymagającym jednak ścisłej kwalifikacji prawnej w ramach przepisów prawa karnego (wyrok NSA z dnia 23 lutego 2017 r., I OSK 1743/15, Legalis nr 1722893).

37 Wyrok WSA w Warszawie $z$ dnia 24 maja 2017 r., II SA/Wa 190/17, Legalis $\mathrm{nr} 1649744$.

${ }^{38}$ Wyrok NSA z dnia 5 lipca 2017 r., I OSK 1026/16, Legalis nr 1663946 i tam powołany wyrok WSA w Warszawie $z$ dnia 24 maja 2005 r., II SA/Wa 160/05, Legalis nr 105325; wyrok WSA w Gorzowie Wielkopolskim z dnia 21 stycznia 2010 r., II SA/Go 970/09, Legalis nr 250462.

39 Wyrok NSA z dnia 8 stycznia 2015 r., I OSK 1334/13, Legalis nr 1200087.

40 Wyrok WSA w Warszawie $z$ dnia 13 lutego 2015 r., II SA/Wa 1487/14, Legalis nr 1244288. 
łączyłoby się z popełnieniem wykroczenia ${ }^{41}$. Jeśli zatem rozkaz lub polecenie służbowe obligowałoby policjanta do niewykonywania czynności służbowych, niepełnienia służby, pozostawania poza miejscem jej pełnienia itp., to musi on je bezwzględnie wypełnić.

Niedopełnienie ciążących na funkcjonariuszu obowiązków skutkuje uznaniem takiej nieobecności jako nieusprawiedliwionej. Wówczas konieczne jest potrącenie policjantowi odpowiedniej części uposażenia przy najbliższej wypłacie, w granicach określonych w art. 126 ust. 2 ustawy o Policji. Potrącenie, jak wynika z powyższego, jest instrumentem prawnym o charakterze represyjnym, pozwalającym na egzekwowanie od policjanta nienależnie pobranej części uposażenia. Zwrot ten nie następuje jednak bezpośrednio z kwoty nienależnie wypłaconego uposażenia, ale z kolejnego „najbliższego" uposażenia, które należne jest funkcjonariuszowi za kolejny okres (miesiąc) pełnienia służby i które podlega wypłacie. Innymi słowy, potrącenie jest roszczeniem podmiotu zatrudniającego jakie ma do policjanta o zwrot nienależnie wypłaconego świadczenia w postaci uposażenia (bądź jego części) $z$ uwagi na brak po stronie tego ostatniego świadczenia wzajemnego, tj. nieusprawiedliwionego niepełnienia przez policjanta służby w danym okresie.

Odmienną instytucją jest $z$ kolei zawieszenie, które ma charakter stricte prewencyjny, tj. zabezpieczający. Ma zapobiec wypłacie policjantowi nienależnego uposażenia, tym samym - następczej egzekucji nienależnie wypłaconego policjantowi uposażenia, a co za tym idzie chroni interes służby. Jest środkiem tymczasowo pozbawiającym policjanta możliwości dysponowania uposażeniem, które winno, co do zasady, być mu wypłacone. Przepis art. 126 ust. 1 ustawy o Policji ustanawia trzy przesłanki, które warunkują zastosowanie tej instytucji ${ }^{42}$. Są nimi: samowolne opuszczenie miej-

${ }^{41}$ Wyrok WSA w Gdańsku z dnia 9 marca 2017 r., III SA/Gd 65/17, Legalis nr 1597018.

${ }^{42}$ Każda $z$ nich jest samodzielną i odrębną podstawą do zawieszenia policjantowi uposażenia (wyrok WSA w Warszawie z dnia 10 kwietnia 2018 r., II SA/Wa 1207/17, Legalis nr 2259304; a także wyrok WSA w Szczecinie z dnia 24 stycznia 2019 r., II SA/Sz 1165/18, Legalis nr 1881247; wyrok WSA w Szczecinie z dnia 31 maja 2017 r., II SA/Sz 394/17, Legalis nr 1635705; 
sca pełnienia służby, pozostawanie poza nim lub niepodejmowanie przez policjanta służby ${ }^{43}$. Przesłanki te nie są tożsame $z$ tą, która warunkuje potrącenie uposażenia. Przesłanki niezbędne do zawieszenia uposażenia odwołują się bowiem do stanów faktycznych, które jeszcze nie mogą być kwalifikowane jako nieusprawiedliwiona nieobecność w służbie. Są to okoliczności, co do których nie istnieje $\mathrm{w}$ danym momencie pełna wiedza, czy będą mogły zostać zakwalifikowane jako usprawiedliwiona albo nieusprawiedliwiona nieobecność w służbie. Konstrukcja ta pozwala zabezpieczyć środki, jeśli policjant jest nieobecny w służbie, bo opuścił samowolnie miejsce jej pełnienia, pozostaje poza nim lub nie podejmuje tej służby, ale nieznana jest jeszcze przyczyna tego stanu rzeczy i okoliczności, które do tego doprowadziły. Zmaterializowanie się choćby jednej z nich uzasadnia zawieszenie uposażenia, począwszy od tego uposażenia, które podlegałoby płatności w najbliższym czasie.

Instrument ten czasowo wstrzymuje wykonanie obowiązku wynikającego $z$ art. 105 ust. 2 ustawy o Policji. Służy zatem temu, aby policjant, który w danym czasie nie świadczy służby, choć w danym momencie brak dostatecznej wiedzy o przyczynach takiego stanu rzeczy, nie pobierał kolejnego uposażenia do czasu ustalenia, czy z tytułu tej nieobecności uposażenie mu przysługuje, a jeśli tak, to $\mathrm{w}$ jakim wymiarze. Instrument ten ma ex definitione charakter temporalny, bo pozwala na wstrzymanie się z wypłatą uposażenia na czas niezbędny do ustalenia okoliczności istotnych dla wyjaśnienia zaistniałego stanu faktycznego, a w konsekwencji do właściwego zakwalifikowania nieobecności funkcjonariusza w służbie: jako usprawiedliwionej bądź nieusprawiedliwionej. Tym samym służy do ustalenia, czy uposażenie za dany okres jest mu należne (w pełnym albo niepełnym wymiarze), czy też nie. Uznanie nieobecności za usprawiedliwioną powoduje konieczność wypłaty zawieszonego

wyrok WSA w Warszawie z dnia 22 października 2015 r., II SA/Wa 307/15, Legalis nr 1393891).

${ }^{43}$ A. Michałek, M. Tokarski, w: Ł. Czebotar, Z. Gądzik, A. Łyżwa, A. Michałek, A. Świerczewska-Gąsiorowska, M. Tokarski, Ustawa o Policji. Komentarz, Warszawa 2015, s. 638 - wyjaśnienie znaczenia tych pojęć. 
uposażenia. $Z$ kolei w przypadku ustalenia, że nieobecność była nieusprawiedliwiona, następuje jego utrata - w wysokości proporcjonalnej do tej absencji. Policjant traci bowiem za każdy dzień nieobecności 1/30 część uposażenia miesięcznego. Nie traci on zatem prawa do uposażenia $z$ chwilą jego zawieszenia. Nie jest to cel tej instytucji, bo zmierza ona nie do trwałego pozbawienia policjanta tego prawa, ale do wstrzymania się z jego wpłatą do czasu ustalenia, czy w ogóle jest ono należne funkcjonariuszowi. Czas trwania tego zawieszenia jest więc uzależniony od czasu nieobecności funkcjonariusza w służbie. Jej zakończenie pozwala ją właściwie zweryfikować, ocenić i zakwalifikować jako usprawiedliwioną albo nie.

Przełożony właściwy w sprawach osobowych podejmuje decyzję o zawieszeniu uposażenia na podstawie okoliczności istniejących w dniu jej wydania, tj. gdy policjanta nie ma w służbie i brak jest informacji co do przyczyn tej absencji. $Z$ uwagi jednak na fakt, że za ten okres (co do zasady) uposażenie zostało mu wypłacone $z$ góry, zawieszenie musi odnieść się do najbliższego uposażenia, tj. tego, które powinno być wypłacone w najbliższym terminie płatności. Wobec tego przełożony ten niejako antycypuje, że trwająca nieobecność funkcjonariusza przedłuży się na kolejny okres (miesiąc) służby, za który należałoby mu wypłacić uposażenie $z$ góry. Jeśli bowiem funkcjonariusz stawi się do służby jeszcze w tym samym miesiącu, w którym wydano decyzję o zawieszeniu uposażenia, to może on wskazać okoliczności swojej nieobecności, a tym samym umożliwić jej odpowiednie zakwalifikowanie. Ten sam skutek nastąpi, jeśli policjant nie stawi się do służby, ale przekaże we właściwym trybie i w odpowiedniej formie informacje, które będą usprawiedliwiać jego absencję. Usprawiedliwienie nieobecności skutkuje koniecznością wypłaty policjantowi zawieszonego uposażenia. Jeśli natomiast stawi się on w tym samym miesiącu, ale nie przedstawi okoliczności uzasadniających przyjęcie, że nieobecność ta była usprawiedliwiona, wówczas implikuje to konieczność zastosowania instytucji potrącenia uposażenia $z$ najbliższego uposażenia, tj. tego, które podlegałoby najbliższej wypłacie, w całości lub w części, stosownie do okresu nieusprawiedliwionej nieobecności. Potrącenie następuje $z$ uposażenia, które uprzednio było zawieszone, a które wskutek odpadnięcia podstaw do tego zawieszenia stało się uposażeniem podlegającym 
kolejnej wypłacie. Jeśli natomiast istniałyby wątpliwości co do kwalifikacji absencji jako usprawiedliwionej albo nieusprawiedliwionej, wówczas wobec odpadnięcia podstaw do zawieszenia uposażenia podlegałoby ono wypłacie, a dopiero usunięcie wymienionych wątpliwości dałoby podstawę do ewentualnego potrącenia uposażenia za okres nieusprawiedliwionej nieobecności policjanta służbie z kolejnego najbliższego uposażenia podlegającego wypłacie. Podobnie rzecz się ma w sytuacji, gdy policjant stawi się do służby w miesiącu, za który zawieszono mu uposażenie (albo w kolejnych miesiącach). Usprawiedliwienie nieobecności skutkuje koniecznością wypłaty uprzednio zawieszonego uposażenia. Nieusprawiedliwiona nieobecność w służbie powoduje utratę uposażenia, które uprzednio było zawieszone, bo stanowiło ono zabezpieczenie przed nienależną jego wypłatą, a także jeśli to konieczne, potrącenie $z$ kolejnych najbliższych uposażeń podlegających wypłacie, stosowanie do okresu nieusprawiedliwionej nieobecności policjanta w służbie.

Dodać również należy, że nie każde odpadnięcie podstaw zawieszenia uposażenia łączy się automatycznie $z$ koniecznością jego wypłaty. Są sytuacje, w których wypłata uposażenia uniemożliwiałaby następczą jego egzekucję. Są to przypadki gdy potrącenie nie mogłoby nastąpić $z$ uposażenia podlegającego najbliższej wypłacie z uwagi na utratę przez policjanta prawa do uposażenia. Funkcjonariusz traci prawo do uposażenia $z$ chwilą zwolnienia ze służby w Policji. W takich sytuacjach zawieszenie uposażenia zmienia swoją funkcję. Nie stanowi wówczas zabezpieczenia przed nienależną wypłatą uposażenia za kolejny okres (miesiąc) służby, gdyż funkcjonariusz już jej nie pełni w kolejnym miesiącu. Zawieszenie stanowi wtedy zabezpieczenie dla ewentualnego potrącenia, które nastąpi, jeśli zostanie ustalone w sposób niebudzący wątpliwości, że okres nieświadczenia przez tego policjanta służby w miesiącu, w którym nastąpiło zawieszenie uposażenia, jest nieusprawiedliwioną nieobecnością. Stanowi tym samym gwarancję zabezpieczenia środków, z których można dokonać potrącenia uposażenia. Przeciwne stanowisko prowadziłoby do wniosku, zgodnie $z$ którym $w$ takich sytuacjach zwrot uprzednio zawieszonego uposażenia następowałby w całości, a potrącenie nie mogłoby nastąpić z kolejnego uposażenia 
podlegającego wypłacie, tego ostatniego bowiem nie byłoby, gdyby policjant zwolnił się ze służby w Policji.

Istotne jest także to, że przepisy dotyczące zawieszenia i potrącenia uposażenia stosuje się $\mathrm{w}$ razie zawinionej niemożności pełnienia przez policjanta obowiązków służbowych (art. 126 ust. 3 ustawy o Policji ${ }^{44}$. Nie dotyczy to zatem sytuacji niezależnych od samego policjanta, za które nie może on ponosić winy, w szczególności za zdarzenia zewnętrzne, niemożliwe do przewidzenia, którym skutkom nie mógł on zapobiec, np. zdarzenia związane $z$ działaniami sił przyrody.

Z kolei zgodnie $\mathrm{z}$ art. 126 ust. 4 ustawy o Policji policjantowi, który rozpoczyna urlop bezpłatny w ciągu miesiąca kalendarzowego, przysługuje uposażenie w wysokości 1/30 uposażenia miesięcznego za każdy dzień poprzedzający dzień rozpoczęcia takiego urlopu. Jeżeli policjant pobrał już uposażenie za czas urlopu bezpłatnego, potrąca się mu odpowiednią część uposażenia przy najbliższej wypłacie. Zaznaczyć tylko należy, że przepis ten stanowi potwierdzenie reguły, zgodnie $z$ którą uposażenie przysługuje, co do zasady, za pełnioną przez policjanta służbę. $Z$ treści art. 85 ustawy o Policji wynika, że policjantowi można udzielić urlopu bezpłatnego z ważnych przyczyn. Zatem policjant może przebywać na urlopie bezpłatnym, jeśli zostanie mu on udzielony. Urlopu bezpłatnego udziela przełożony właściwy w sprawach osobowych na zasadach i w trybie określonym w rozdziale 4 „Urlop zdrowotny i bezpłatny” Rozporządzenia z dnia 19 września 2014 r. Ministra Spraw Wewnętrznych w sprawie urlopów policjantów. Wynika z tego, że udzielenie urlopu bezpłatnego ma charakter fakultatywny i zależne jest od uznania przełożonego właściwego w sprawach osobowych. Jego

44 „Sytuację gdy policjant stawia się do służby, lecz nie może jej podjąć z uwagi na brak aktualnych badań lekarskich, kwalifikować należy jako niemożność podjęcia obowiązków służbowych, o której mowa w ust. 3 art. 126 ustawy z dnia 6 kwietnia 1990 r. o Policji (t.j. Dz.U. z 2015 r. poz. 355 ze zm.)" (wyrok WSA w Szczecinie $z$ dnia 25 sierpnia 2016 r., II SA/Sz 395/ 16, Legalis nr 1547857). Por. także wyrok NSA $z$ dnia 8 listopada 2018 r., I OSK 1106/18, Legalis nr 2298765; wyrok WSA w Szczecinie z dnia 14 grudnia 2017 r., II SA/ /Sz 1194/17, Legalis nr 1729123. 
zgoda na udzielenie urlopu nie wymaga jednak wydania rozkazu personalnego ${ }^{45}$.

\section{Uwagi końcowe}

Zagadnienia związane $\mathrm{z}$ zawieszeniem i potrąceniem uposażenia są, jak wykazano, złożone i wywołują szereg wątpliwości wśród podmiotów zobowiązanych do stosowania tych instytucji. Celem niniejszego opracowania było wskazanie najistotniejszych elementów tych konstrukcji prawnych. Oczywiście nie wyczerpuje to całości przedmiotowego zagadnienia, stanowi jednak punkt wyjścia do dalszych pogłębionych analiz w tym zakresie.

Instytucje te zostały wprowadzone do pragmatyki służbowej po to, by stanowiły $z$ jednej strony instrument służący do czasowego zabezpieczenia przed wypłatą uposażenia w sytuacjach, gdy brak jest dostatecznej informacji co do przyczyn nieświadczenia przez policjanta służby przez pewien czas, a $z$ drugiej do trwałego pozbawienia go prawa do tego uposażenia za okres nieusprawiedliwionej nieobecności w służbie. Instytucja zawieszenia ma zatem charakter prewencyjny, bo pozwala dyscyplinować funkcjonariuszy, którzy z nieustalonych przyczyn nie pełnią służby. Umożliwia zatem wstrzymanie się z jego wypłatą do czasu ustalenia przyczyn tej absencji, a tym samym ustalenie, czy w ogóle jest ono policjantowi należne. Potrącenie $z$ kolei ma charakter represyjny. Trwale pozbawia funkcjonariusza uposażenia za okres nieusprawiedliwionej nieobecności w służbie. Obie instytucje zostały ustanowione dla dobra służby, gdyż chronią jej interes, a w szerszym znaczeniu: interes społeczny. W tym kontekście pozytywnie należy ocenić zasadność zamieszczenia obu konstrukcji prawnych w pragmatyce służbowej. Służba publiczna wymaga od funkcjonariuszy jej świadczenia, a uposażenie winno być ekwiwalentem za pełnioną

${ }^{45}$ Zgodnie bowiem z $§ 3$ ust. 4 Rozporządzenia Ministra Spraw Wewnętrznych z dnia 14 maja 2013 r. w sprawie szczegółowych praw i obowiązków oraz przebiegu służby policjantów formy tej nie stosuje się do udzielania urlopów. 
służbę i gotowość do wykonywania zadań służbowych. Sytuacje, w których policjantowi należne jest uposażenie, mimo że nie pełni on służby, powinny być wyjątkiem od przyjętej reguły. Instytucja ta zatem uwzględnia zarówno interes społeczny (interes służby), jak i słuszny interes policjanta, którego decyzja ta dotyczy. W obliczu jednak podniesionych argumentów w przypadku kolizji pomiędzy tymi dwoma dobrami interes policjanta musi ustąpić przed interesem służby. Gdyby dać prymat temu pierwszemu, osiągnięcie celu, jakim jest realizacja ustawowych zadań Policji, mogłoby okazać się nie tylko utrudnione, ale wręcz niemożliwe.

\title{
STRESZCZENIE
}

\author{
Zawieszenie oraz potrącenie \\ policjantowi uposażenia na podstawie art. 126 ustawy \\ z dnia 6 kwietnia 1990 r. o Policji
}

Niniejszy artykuł został poświęcony problematyce zawieszenia oraz potrącenia uposażania policjantowi. Uposażanie przysługuje policjantowi za pełnioną służbę. Jest to ekwiwalent za czas poświęcony służbie oraz rekompensata za zwiększoną dyspozycyjność i gotowość podjęcia działań. Istnieją jednak przypadki, które pozwalają na zawieszenie uposażenia, a także jego potrącenie. Służy temu konstrukcja prawna zamieszczona w art. 126 ustawy o Policji. Stanowi ona nie tylko instrument o charakterze prewencyjnym, ale może być instrumentem represyjnym - dyscyplinującym policjantów, którzy z nieuzasadnionych przyczyn nie pełnili służby i nie wykonywali obowiązków służbowych. Uwagę skoncentrowano na celu, który ta instytucja ma osiągnąć, a także omówiono przesłanki warunkujące zastosowanie obu konstrukcji prawnych.

Słowa klucze: Policja; policjant; służba w policji; zawieszenie uposażenia; potrącenie uposażenia 


\title{
SUMMARY
}

\author{
Suspension and deduction \\ from the salary for service of the Police officer based \\ on the Article 126 Act of 6 April 1990 on the Police
}

This paper was entirely devoted to the issues of suspension and deduction from the salary for service of the Police officer. The Police officer is entitled to a salary for the service he performs. It is the equivalent of time spent in the service and compensation for increased availability and readiness to undertake activity. However, there are cases that allow for the suspension of the salary for service as well as its deduction. Legal structure included in Art. 126 Act on the Police serves this purpose. Its is established not only as the instrument of preventive measures but it can be also used as repressive measures - disciplining Police officers who for unreasonable reasons have not been performing service and realizing duty of service. Attention was focused on the aim of this institution which has to be achieved and prerequisites for applying both legal structures were discussed.

Keywords: Police; policeman (police officer); police service; suspension from the salary for service; deduction from the salary for service

\section{BIBLIOGRAFIA}

Bogdalski P., Świderski M., Wojtaszczyk K. A. (red.), Słownik wiedzy o Policji, Warszawa 2015.

Czebotar Ł., Gądzik Z., Łyżwa A., Michałek A., Świerczewska-Gąsiorowska A., Tokarski M., Ustawa o Policji. Komentarz, Warszawa 2015.

Duniewska Z., Jaworska-Dębska B., Stahl M. (red.), Prawo administracyjne materialne. Pojęcia, instytucje, zasady, Warszawa 2014.

Gacek P., Czas stużby a czas pracy - wybrane aspekty. Przyczynek do dyskusji, „Policja. Kwartalnik kadry kierowniczej Policji” 2014, nr 2.

Gacek P., Nawiazanie stosunku służbowego z funkcjonariuszem Policji, „Administracja: teoria, dydaktyka, praktyka” 2011, nr 2(23).

Gacek P., Stużba petniona przez policjanta $w$ ramach dyżuru domowego, „Policja. Kwartalnik kadry kierowniczej Policji” 2017, nr 2.

Grześków M., Nawiązywanie stosunków zatrudnienia $w$ służbach zmilitaryzowanych, Warszawa 2020, Legalis. 
Kotowski W., Ustawa o Policji. Komentarz, Warszawa 2008.

Kuczyński T., Mazurczak-Jasińska E., Stelina J., Stosunek służbowy, w: System prawa administracyjnego. Tom 11, red. R. Hauser, Z. Niewiadomski, A. Wróbel, Warszawa 2011.

Lew M., Policja, w: Stosunek służbowy $w$ formacjach mundurowych, red. W. Maciejko, P. Szustakiewicz, 2016, Legalis.

Liwo M., Status służb mundurowych i funkcjonariuszy $w$ nich zatrudnionych, Warszawa 2013.

Maciejko W., Osobowe prawo administracyjne, Warszawa 2008.

Maciejko W., Korcz-Maciejko A., Postępowanie w sprawach osobowych $w$ Policji, Wrocław 2010.

Maciejko W., Rojewski M., Suławko-Karetko A., Postępowanie administracyjne. Zarys wykładu części szczególnej, Warszawa 2011.

Opaliński B., Szustakiewicz P., Policja. Studium administracyjnoprawne, Warszawa 2013.

Opaliński B., Rogalski M., Szustakiewicz P., Uwagi do art. 99, w: Ustawa o Policji. Komentarz, Warszawa 2020, Legalis.

Opaliński B., Rogalski M., Szustakiewicz P., Uwagi do art. 33, w: Ustawa o Policji. Komentarz, Warszawa 2020, Legalis.

Szankin T., Służba w Policji, w: Prawo policyjne, red. M. Czuryk, M. Karpiuk, J. Kostrubiec, K. Orzeszyna, Warszawa 2014.

Szustakiewicz P., Stosunki służbowe funkcjonariuszy służb mundurowych i żołnierzy zawodowych jako sprawa administracyjna, Warszawa 2012.

Tarno J.P., Policja jako organ administracji o kompetencjach szczególnych, w: Policja $w$ strukturach administracji publicznej, red. A. Babiński, P. Bogdalski, Szczytno 2005.

Wieczorek M., Charakter prawny stosunków służbowych funkcjonariuszy służb mundurowych, Toruń 2017.

Zając P., Uwagi do art. 99, w: Ustawa o Policji. Komentarz, red. K. Chałubińska-Jentkiewicz, J. Kurek, Warszawa 2020, Legalis.

Zieliński T., Stosunek prawa pracy do prawa administracyjnego, Warszawa 1977.

Zorska M., Komentarze do ustaw z 31 stycznia 1950 r. o stosunku stużbowym funkcjonariuszów Milicji Obywatelskiej i z 31 stycznia 1959 r. o zaopatrzeniu emerytalnym funkcjonariuszów Milicji Obywatelskiej $i$ ich rodzin, Warszawa 1960. 
